It does not help an author attempting to communicate how this affected modern society to have an apparent aversion to technology and mathematics. On Hull's approach to learning theory, for example, she says, "from 1929 to 1936 the mechanisms become increasingly complex, like fine-spun webs". But she does not see that Hull's rather modestly complex work was a remote precursor of modern attempts to create artificial intelligence, and she can scarcely have any acquaintance with the sorts of software models they involve. Hull just didn't have digital computers to play with. ${ }^{\alpha}$ Hull loved logarithms and seems to have had a fetish for mathematics," she remarks. Whether this would be a similarly perverse trait in a quantum physicist I cannot guess, but as most of the attempt to develop scientific psychology has involved elements of quantification, I suppose her objection must be to that enterprise as a whole and in principle. It would be a more persuasive objection if it were based on a clearer, more comprehensive and more penetrating grasp of its target.

Steve Blinkhorn is at Psychometric Research and Development, Brewmaster House, The Maltings, StAlbans AL13HT, UK.

\title{
EXHIBITION
}

\section{Casting a long shadow}

\author{
Melancholy: Genius and Insanity in the \\ West \\ National Galleries of the Grand Palais in \\ Paris, France, until 16 January 2006 and the \\ Neue Nationalgalerie in Berlin, Germany, \\ from 16 February to 7 May 2006.
}

\section{Laura Spinney}

In Albrecht Dürer's 1514 engraving Melancholy, a winged female creature sits in semidarkness, surrounded by scientific symbols, resting her head on her hand, a pensive expression on her face. It is an image that has been reproduced again and again over the centuries, and it conveys the sense of solitude and depression of the spirit out of which springs both madness and the greatest acts of artistic and scientific invention. Dürer created his image in what might be called the golden age of melancholy', when that state of mind was closely linked with creativity.

The exhibition Melancholy: Genius and Insanity in the West sets out to track the changing attitudes to melancholy over the centuries. It shows how during different epochs it has been claimed by intellectuals, mystics, scientists and artists in turn. The ancient Greeks recognized the power of melancholic genius - what Aristotle called "the melancholy of exceptional men" - but with the arrival of Christianity this state of mind took on a diabolical significance.

The early Christians went out into the desert to wrestle with demons, which often appeared in the form of visions or obsessions. They were occasionally overcome by a kind of spiritual torpor that was regarded as a deadly $\sin$. Medieval thinkers saw no creative energy in melancholy, and it was during the Middle Ages that the contemplative state was first associated with mania in the form of disturbing visions. This can be seen in Hiëronymus Bosch's painting The Temptation of St Anthony and is reflected in our modern diagnosis of bipolar depression.

The Greeks attributed melancholy to the spleen and black bile. Autumn was its season, dusk its time of day, earth its element and Saturn its planet. After the Renaissance, the progressive Florentines resurrected melancholy as a

source of divine inspiration, and in Dante's The Divine Comedy it was from the sphere of Saturn that the poet saw the dazzling golden ladder that led upwards to contemplation of the deity.

The children of Saturn eventually came to include all social outcasts as well as people of melancholic temperament, and one of the themes in the exhibition is the loneliness of the monster. Goya's painting Colossus depicts a ghostly figure who strides over the landscape and the terrified, fleeing peasants; Charles Le Brun drew men resembling wolves; and the werewolf itselfhas a long association with

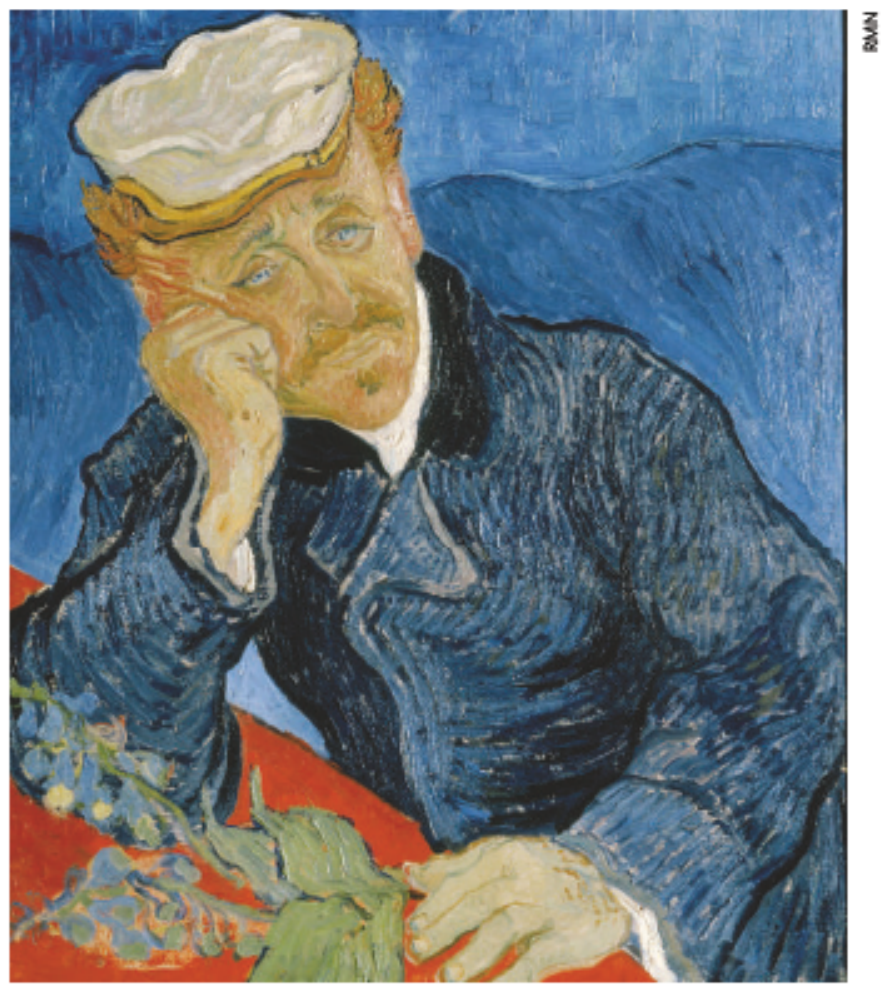

A picture of melancholy: Van Gogh's Partrait of Dr Gachet.

melancholy. William Blake's Nebuchadnezzar from the painting of the same name is half man, half beast. Mad, naked and solitary, he crawls into a cave, fleeing the sun. The melancholic landscape is often bare and dotted with ruins. In the seventeenth century, Cervantes created the melancholic dreamer Don Quixote, but melancholy soon came to be seen as an affliction of island peoples, particularly the British.

Only music could reach the soul of the melancholic and lift his spirit, so David played his harp to soothe the disturbed King Saul. In Fernand Khnopff's painting Listening to Schumann, a woman whose face is hidden by her hand seems marooned as she sits in the centre of a drawing room, dressed in black, bathed in a sombre, late afternoon light. Schumann himself suffered from depression and eventually committed suicide.

With the arrival of the eighteenth century and the Enlightenment, the medical and artistic interpretations of melancholy diverged. In the world of science and rational thought, melancholy came to signify irrationality and madness. The medical diagnosis monomania was used to describe the obsessive aspect of mania, and was later replaced by the broader diagnosis of bipolar depression, which covered both the manic and the depressive poles of the condition. To artists, in contrast, melancholy suggested solitude and meditation. Van Gogh's Portrait of Dr Gachet combines both interpretations. The artist's model studied melancholy at the Pitié-Salpetrière hospital in Paris, and in the painting adopts the time-honoured pose of the wistful melancholic, head on hand. Meanwhile Ron Mueck's larger-than-life sculpture of a naked man cowering in a corner, chin in hand, speaks strongly of the asylum.

Science no longer has any use for the concept of melancholy, and the most widely accepted meaning now is the artistic one, what Victor Hugo described as "more than gravity and less than sadness". The modern concept of melancholy seems to be best summed up by Giorgio de Chirico's painting from 1912 showing a tomb bearing the marble figure of a reclining woman who rests her head on her hand. The tomb has engraved on it the word melanconia, and it casts a long, long shadow.

Laura Spinney is a freelance writer based in London and Paris. 